УДК 618.164 - 008.6 - 06:618.173] - 08

DOI 10.11603/24116-4944.2018.1.8796

\author{
๑О. М. Павловська, К. М. Павловська, Ж. О. Краснова
}

Одесъкий національний медичний університет

\title{
«ТЕРАПЕВТИЧНЕ ВІКНО» ПРИ МЕДИКАМЕНТОЗНОМУ ЛІКУВАННІ ГЕНТТОУРИНАРНОГО МЕНОПАУЗАЛЬНОГО СИНДРОМУ В ЖІНОК
}

\begin{abstract}
Мета дослідження - вивчити ефективність медикаментозного лікування генітоуринарного менопаузального синдрому в жінок залежно від тривалості його перебігу.

Матеріали та методи. Було обстежено 78 жінок віком 48-74 роки з менопаузальними генітоуринарними порушеннями. Пацієнток було розділено на три групи залежно від тривалості менопаузального генітоуринарного синдрому: до 3 років - I група, 3-5 років - II група, більше 5 років - III група. Усім пацієнткам призначали однакову медикаментозну терапію протягом 6 місяців, яка включала естрогенвмісний препарат, фрітоуросептик та анксіолітик. Також обов'язково рекомендували дотримуватись певних правил харчування та щоденне виконання прав Кегеля. Усім пацієнткам проводили рутинне клініко-лабораторне обстеження. Ступінь виразності генітоуринарної диссрункції визначали за допомогою індексу вагінального здоров'я за G. Bachmann та шкали D. Barlow. Для визначення стадії стресового нетримання сечі використовували добовий Рad-тест за стандартами ICS.

Результати дослідження та їх обговорення. У пацієнток, які страждали від проявів генітоуринарної дисфрункції не більше 5 років (I та II групи), виразні атрофічні зміни в піхві були відсутні, проте серед жінок III групи цей показник складав

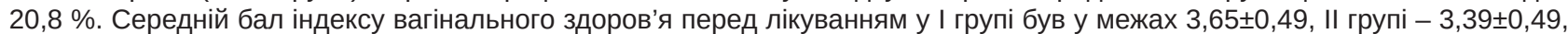

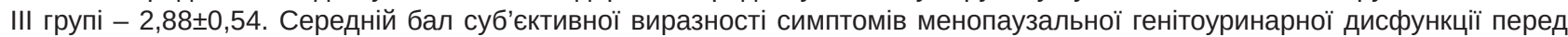
початком лікування у пацієнток I групи становив $(1,92 \pm 0,56)$ бала, II групи - $(2,36 \pm 0,62)$ бала, III групи - $(3,08 \pm 0,65)$ бала. Результати досліджень після завершення лікування продемонстрували значну позитивну клінічну динаміку в жінок I групи, у яких тривалість менопаузальних порушень тривала не більше 3 років.

Висновки. Одним із вирішальних фракторів ефективності лікування менопаузальних генітоуринарних порушень є фактор часу. Результативність заходів корекції зазначеної патології найкраща, якщо тривалість порушень не більше 3 років. При більших термінах перебігу ефективність лікування зменшується та стає доволі малоефективною.
\end{abstract}

Ключові слова: генітоуринарний менопаузальний синдром; генітоуринарна диссункція; індекс вагінального здоров'я; нетримання сечі.

\section{«ТЕРАПЕВТИЧЕСКОЕ ОКНО» ПРИ МЕДИКАМЕНТОЗНОМ ЛЕЧЕНИИ ГЕНИТОУРИНАРНОГО МЕНОПАУЗАЛЬНОГО СИНДРОМА У ЖЕНЩИН}

Цель исследования - изучить эфффективность медикаментозного лечения генитоуринарного менопаузального синдрома у женщин в зависимости от его продолжительности.

Материалы и методы. Было обследовано 78 женщин в возрасте 48-74 года с менопаузальными генитоуринарными нарушениями. В зависимости от продолжительности течения менопаузального генитоуринарного синдрома пациентки были разделены на три группы: до 3 лет - I группа, 3-5 лет - II группа, более 5 лет - III группа. Всем пациенткам назначали одинаковую медикаментозную терапию в течение 6 месяцев, которая включала эстрогенсодержащий препарат, фритоуросептик и анксиолитик. Также настоятельно рекомендовалось соблюдать определенные правила питания и ежедневно выполнять упражнения Кегеля. Всем пациенткам проводилось рутинное клинико-лабораторное обследование согласно действующим клиническим протоколам. Степень выраженности генитоуринарной дисфункции оценивали с помощью индекса вагинального здоровья по G. Bachmann и шкалы D. Barlow. Для определения стадии стрессового недержания мочи использовали суточный Pad-тест по стандартам ICS.

Результаты исследования и их обсуждение. У пациенток, страдающих генитоуринарной диссункцией не более 5 лет (I и II группы), выраженные атрофические изменения во влагалище отсутствовали, однако среди женщин III группы этот показатель составил 20,8 \%. Средний балл индекса вагинального здоровья перед началом лечения в I группе был

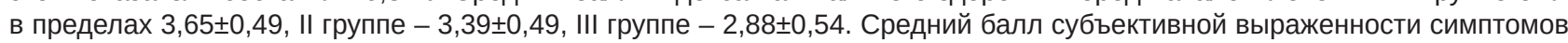
менопаузальной генитоуринарной диссункции перед началом лечения у пациенток I группы составил $(1,92 \pm 0,56)$ балла, II группы - $(2,36 \pm 0,62)$ балла, III группы - $(3,08 \pm 0,65)$ балла. Результаты исследований после завершения курса лечения продемонстрировали значительную положительную клиническую динамику у женщин I группы, у которых продолжительность менопаузальных нарушений длилась не более 3 лет.

Выводы. Одним из решающих факторов эффрективности лечения менопаузальных генитоуринарных нарушений является фрактор времени. Наилучшие результаты при коррекции данной патологии достигаются, если ее продолжительность составляет не более 3 лет. При большей продолжительности эфрфективность лечения становится меньшей и достаточно малоэффрективной.

Ключевые слова: генитоуринарный менопаузальный синдром; генитоуринарная диссрункция; индекс вагинального здоровья; недержание мочи.

"THERAPEUTIC WINDOW" IN DRUG TREATMENT OF THE GENITO-URINARY MENOPAUSAL SYNDROME IN WOMEN

The aim of the study - to investigate the effectiveness of the medication treatment of the genito-urinary menopausal syndrome in women, depending on its duration.

Materials and Methods. 78 women aged 48-74 with menopausal genito-urinary disorders were examined. Depending on the duration of the menopausal genitourinary syndrome, the patients were divided into three groups: up to 3 years - Group I, 3-5 
years - Group II, more than 5 years - Group III. All patients had been given the same drug therapy for 6 months, which included estrogen-containing drug, phyto-uroseptic and anxiolytic. It was also strongly recommended to follow certain dietary rules and perform Kegel exercises daily. All patients were routinely clinically and laboratory tested, according to the current clinical protocols. The severity of the genitourinary dysfunction was assessed using the vaginal health index of G. Bachmann and D. Barlow scale. To determine the stress urinary incontinence stage, the daily Pad test was used by ICS.

Results and Discussion. The patients suffering from the genitourinary dysfunction for not more than 5 years (group I and II) had atrophic changes in the vagina, however, among women in group III, this figure was $20.8 \%$. The average score of vaginal health index before the treatment in group I was (3.65 \pm 0.49$)$, in group II - (3.39 \pm 0.49$)$, in group III - (2.88 \pm 0.54$)$. The mean score of subjective manifestation of the menopausal genitourinary dysfunction symptoms before the treatment in patients of group I was $(1.92 \pm 0.56)$ points, group II $-(2.36 \pm 0.62)$ points, group III $-(3.08 \pm 0.65)$ points. The results of the study after the completion of the treatment showed a significant positive clinical dynamics in women of I group, in whom the duration of menopausal disorders lasted not more than 3 years.

Conclusions. One of the decisive factors in the treatment of menopausal genitourinary disorders is the time factor. The best results in correction of this pathology are achieved if its duration is not more than 3 years. In longer duration, the effectiveness of the treatment becomes smaller and rather ineffective.

Key words: genitourinary menopausal syndrome; genitourinary dysfunction; index of vaginal health; urinary incontinence.

ВСтУп. Загальноприйнятою дефрініцією клімактеричного синдрому прийнято вважати патологічний стан, який виникає в жінок внаслідок природних вікових змін організму та супроводжується поліморфними нервово-психічними, вегетосудинними й обмінно-тросрічними розладами [1, 2]. Відповідно до результатів фрундаментальних клінічних досліджень, формування вищезазначеного симптомокомплексу пов'язано з дизадаптацією, отже, порушенням закономірних хронологічних механізмів регуляції вікової нервово-ендокринної та метаболічної рівноваги у відповідь на прогресуюче згасання активності яєчників $[3,4]$.

Практикуючими лікарями та науковцями на сьогодні систематизована та вичерпно деталізована клінічна палітра клімактеричного синдрому [5, 6]. Так, до ранніх проявів відносять вазомоторні порушення (раптове відчуття жару в ділянці верхньої частини тулуба, шиї та голови, підвищена пітливість, озноб, головний біль, запаморочення, тахікардія, симпатико-адреналові й вагоінсулярні кризи), емоційно-вегетативні (нестійкість настрою та поведінкових/психічних реакцій з елементами істеричної психопатії та/або сенестопатії, що нерідко супроводжується фрормуванням екзальтованих, сентиментальних або іпохондричних ідей), урогенітальні (сухість піхви, свербіж, відчуття печіння, диспареунія, зниження лібідо, цисталгія, уретральний синдром, нетримання сечі). Пізні ознаки клімактеричного синдрому характеризуються постменопаузальними метаболічними порушеннями (атеросклероз, артеріальна гіпертензія, гіперліпідемія, інсулінорезистентність), неврологічними (зниження когнітивних функцій, пам'яті) та кістково-м'язовими (остеопороз, остеоартрит).

Отже, зрозуміло, що прогресування клімактеричного синдрому неодмінно призводить до поступової психологічної та соціальної ізоляції жінки, тому актуальним на сучасному етапі розвитку медицини залишається продовження активного пошуку, розробка й втілення в повсякденну лікувальну практику безпечних й етіопатогенетично спрямованих методик корекції клімактеричних порушень. Разом з тим, вирішальним фрактором позитивності лікування будь-якого патологічного стану $є$ своєчасність його призначення з урахуванням «терапевтичного вікна» - періоду часу, в межах якого ефективність лікувальних засобів буде найбільшою. На наш погляд, очевидним та незаперечним $є$ твердження, що тільки поєднання таких стрижневих фракторів, як точна діагностика, етіопатогенетично спрямоване і вчасне призначене лікування складають міцний каркас результативності заходів та фрормують умови для сприятливого прогнозу й підвищення якості життя пацієнток, що страждають від клімактеричних розладів.

МЕТА ДОСЛІДЖЕННЯ - вивчити ефективність медикаментозного лікування генітоуринарного менопаузального синдрому в жінок залежно від тривалості його перебігу.

МАТЕРІАЛИ ТА МЕТОДИ. БУЛо обстежено 78 жінок віком 48-74 роки з менопаузальними генітоуринарними порушеннями.

Пацієнток було розділено на три групи:

I група - 26 жінок, які страждали від проявів менопаузального генітоуринарного синдрому протягом до 3 років;

II група - 28 жінок, які скаржились на ознаки менопаузального генітоуринарного синдрому протягом 3-5 років;

III група - 24 пацієнтки, які потерпали від менопаузального генітоуринарного синдрому більше 5 років.

Усім пацієнткам призначали однакову медикаментозну терапію протягом 6 місяців за нижченаведеними схемами.

Овіпол Кліо (Фармприм, Молдова) - гормональний препарат для місцевого застосування, що містить 500 мг естрадіолу (Е3) та $€$ безпечним для жінок клімактеричного віку завдяки відсутності проліферативного ефекту. Призначали по 1 супозиторію (0,5 мг) щоденно протягом 3 тижнів, потім 2 рази на тиждень протягом 4 тижнів, згодом 1 раз на тиждень протягом 3 місяців.

Сальвірен (Лаб. Ліконса, С.А., Іспанія) - комплексний фрітоуросептик, що містить екстракт журавлини, екстракт шавлії та аскорбінову кислоту. Призначали по 1 капсулі 2 рази на добу після прийому їжі протягом 20 діб з 10-денною перервою, 6 курсів.

Грандаксин («Egis» Pharmaceutical Ltd, Угорщина) - анксіолітик, що регулює психовегетативні реакції, а також має помірний психостимулюючий ефект. Препарат не акумулюється в організмі, його метаболіти не мають орармакологічної активності. Призначали по 1 таблетці (50 мг) протягом 3 місяців.

Також пацієнткам наполегливо рекомендувалось дотримуватись певних правил харчування - вживати не менш 2-2,5 літрів рідини протягом дня, пріоритет 
надавати овочевим салатам з лляним маслом, фрруктам, крупам, макаронним виробам, морепродуктам та на період лікування повністю виключити із раціону гостру їжу, прянощі, копчені продукти, міцний кофе, чай, газовані напої, алкоголь. Крім того, пацієнткам необхідно було щоденно виконувати нескладні гімнастичні вправи Кегеля, які сприяють відновленню та поліпшенню тонусу м'язів тазового дна.

Критерії включення до дослідження: наявність ознак менопаузальної генітоуринарної дисорункції - сухість піхви, болісність при статевих зносинах, свербіж і печіння вульви та піхви, часте сечовипускання з епізодами нетримання сечі при кашлі, чиханні, помірних фрізичних навантаженнях.

Критерії виключення з дослідження: наявність у пацієнтки протипоказань до гормональної терапії згідно 3 наказами МОЗ України.

Усім пацієнткам проводили рутинне клініко-лабораторне обстеження. Ступінь виразності генітоуринарної диссрункції визначали за допомогою індексу вагінального здоров'я за G. Bachmann та шкали D. Barlow [7, 8]. Для визначення стадії стресового нетримання сечі використовували добовий Pad-тест за стандартами ICS [9]. Для обробки результатів дослідження використовували метод варіаційної статистики і непараметричні методи за допомогою програм «Excel-2000» i «Statistica for Windows v.6.0».

РЕЗУЛЬТАТИ ДОСЛІДЖЕННЯ ТА ЇХ ОБГОВОРЕННЯ. Середній вік пацієнток I групи склав $(52,2 \pm 1,9)$ року, II групи - $(56,3 \pm 2,4)$ року, III групи - $(65,8 \pm 4,2)$ року.

У дослідженні ступінь атрофрічного процесу у піхві визначали за допомогою критеріїв G. Bachmann у балах. Важливим став виявлений фракт відсутності в обстежених пацієнток нормального значення цього індексу, тобто у всіх жінок мав місце певний ступінь піхвової атрофії. Так, слабкий ступінь (4 бали) цього патологічного стану перед початком лікування був діагностований у 17 (65,4\%) пацієнток I групи, 11 (39,3 \%) - II групи та лише у 2 (8,3 \%) - III групи. Ознаки помірної атрофіії (3 бали) визначались у 9 (34,6 \%) жінок I групи, 17 (60,7 \%) - II групи, 17 (70,8 \%) - III групи. Слід зазначити, що у пацієнток, які страждали від проявів генітоуринарної дисфункції не більше 5 років ( І та II групи), виразні атрофрічні зміни в піхві були відсутні, проте в III групі цей показник склав 20,8\%. Отже, середній бал індексу вагінального здоров'я в I групі був у межах

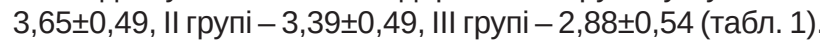

Після проведеного повного курсу лікування відновлення еластичності, pH балансу, вологості та інших показників індексу G. Bachmann відбулось у 13 (50 \%) пацієнток I групи, слабкий та помірний ступінь атрофрії залишились у 11 (42,3 \%) та 2 (7,7 \%) жінок даної групи, відповідно, а

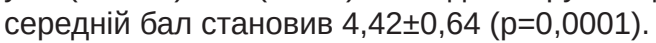

У пацієнток, які страждали від проявів генітоуринарного синдрому протягом 3-5 років (II група), нормалізація показників індексу вагінального здоров'я за G. Bachmann спостерігалась у значно меншої кількості в порівнянні з I групою - лише у 4 (14,3 \%), слабкі атрофрічні знаки піхви збереглись у 16 (57,1 \%), помірні - у 8 (28,6 \%) жінок. Тим не менш, загальний бал був у межах $3,67 \pm 0,61$ ( $p=0,003)$, що свідчило про позитивні результати лікувальних заходів.

У пацієнток III групи після досить тривалого лікування значних змін не відбулось. Слабка атрофія піхви була підтверджена лише у 2 (8,3\%) жінок, у переважної більшостіпомірні й виразні прояви атрофрічного процесу - 21 (87,5\%) та 1 (4,2 \%) відповідно. Індекс вагінального здоров'я становив тільки 3,04 $\pm 0,36$ ( $p=0,103)$.

Цікавим моментом у дослідженні було визначення відповідності виразності об'єктивних ознак генітоуринарних порушень із суб'єктивними відчуттями пацієнток, які оцінювались за допомогою шкали D. Barlow. Так, як «незначна проблема, яка не впливає на повсякденне життя» (1 бал) оцінили свій стан 5 (19,2 \%) жінок I групи, лише 2 (7,1 \%) - II групи, проте жодної з III групи. Як «дискомфорт, що періодично впливає на повсякденне життя» (2 бали) розцінили більшість пацієнток I групи 18 (69,2 \%), 14 (50 \%) - II групи й 4 (16,7 \%) - III групи. Як «виразну рецидивуючу проблему, що впливає на повсякденне життя» (3 бали) описали лише 3 (11,6 \%) жінки I групи, проте 12 (42,9 \%) - II групи та 14 (58,3 \%) III групи. Слід зазначити, що 6 (25 \%) пацієнток III групи, тобто, які звернулись до лікаря після 5 років страждань від генітоуринарних порушень, вважали наявний стан «виразною проблемою, що постійно впливає на повсякденне життя» (4 бали). Отже, середній бал суб'єктивної виразності симптомів менопаузальної генітоуринарної диссрункції перед початком лікування у пацієнток I групи становив $(1,92 \pm 0,56)$ бала, II групи - $(2,36 \pm 0,62)$ бала, III групи - $(3,08 \pm 0,65)$ бала (табл. 2).

Після завершення повного курсу лікувальних заходів 8 (30,8 \%) обстежуваних 3 I групи відмітили значне покращення самопочуття з відсутністю скарг, у більшості пацієнток - 16 (61,5 \%) - «проблема залишилась незначною, проте не впливала на повсякденне життя», у 2 (7,7 \%) - виразність генітоуринарних менопаузальних порушень була оцінена на 2 бали. Пацієнтки II групи оцінили результативність лікування доволі стримано. На 1 бал розцінили виразність симптомів за шкалою D. Barlow лише $3(10,7 \%)$ жінки, на 2 бали - 13 (46,4 \%), на 3 бали - 10 (35,7 \%). Лише 2 (7,1 \%) пацієнтки, які

Таблиця 1. Індекс вагінального здоров'я в обстежуваних пацієнток, бали

\begin{tabular}{|l|c|c||}
\hline \multicolumn{1}{|c|}{ Групи пацієнток } & До лікування & Після лікування \\
\hline I $(\mathrm{n}=26)$ & $3,65 \pm 0,49$ & $4,42 \pm 0,64$ \\
& & $(\mathrm{p}=0,0001)$ \\
\hline II $(\mathrm{n}=28)$ & $3,39 \pm 0,49$ & $3,67 \pm 0,61$ \\
& & $(\mathrm{p}=0,003)$ \\
\hline III $(\mathrm{n}=24)$ & $2,88 \pm 0,54$ & $3,04 \pm 0,36$ \\
& & $(\mathrm{p}=0,103)$ \\
\hline
\end{tabular}

Примітка. p - достовірність різниці між показниками до та після лікування. 
Таблиця 2. Виразність симптомів менопаузальної генітоуринарної дисфункції в обстежуваних пацієнток за шкалою D. Barlow, бали

\begin{tabular}{|l|c|c||}
\hline \multicolumn{1}{|c|}{ Групи пацієнток } & До лікування & Після лікування \\
\hline I $(\mathrm{n}=26)$ & $1,92 \pm 0,56$ & $0,76 \pm 0,59$ \\
& & $(\mathrm{p}<0,001)$ \\
\hline II $(\mathrm{n}=28)$ & $2,36 \pm 0,62$ & $2,11 \pm 0,88$ \\
& & $(\mathrm{p}=0,006)$ \\
\hline III $(\mathrm{n}=24)$ & $3,08 \pm 0,65$ & $2,72 \pm 0,76$ \\
& & $(\mathrm{p}=0,01)$ \\
\hline
\end{tabular}

Примітка. р - достовірність різниці між показниками до та після лікування.

страждали від генітоуринарної диссрункції протягом 35 років, після завершення рекомендованого лікування позбулись суб'єктивних симптомів. Дещо схожа ситуація спостерігалась в III групі - на 1 бал есрективність лікування оцінила лише 1 (4,2\%) пацієнтка, на 2 бали - 6 (25\%), на 3 бали - 13 (54,2\%), на 4 - 4 (16,7\%).

Результати Pad-тесту після завершення лікування також продемонстрували значну позитивну динаміку саме в жінок I групи - більшість - 19 (73,1 \%) обстежуваних позбулись проявів стресового нетримання сечі. У пацієнток II групи результативність лікування в аспекті поліпшення контролю за сечовипусканням також була доволі прийнятною - у 15 (53,6 \%) жінок були відсутні ознаки нетримання сечі, у 13 (46,4 \%) - визначалась 1 стадія. В обстежуваних пацієнток III групи значного покращення не відбулось (табл. 3).

Таблиця 3. Ступінь стресового нетримання сечі в обстежуваних пацієнток

\begin{tabular}{|l|c|c|c|c|c|c||}
\hline \multirow{2}{*}{$\begin{array}{c}\text { Стадії } \\
\text { нетримання сечі }\end{array}$} & \multicolumn{2}{|c|}{ І група $(\mathrm{n}=26)$} & \multicolumn{2}{|c|}{ II група $(\mathrm{n}=28)$} & \multicolumn{2}{|c|}{ III група $(\mathrm{n}=24)$} \\
\cline { 2 - 8 } & до лікування & $\begin{array}{c}\text { після лікуван- } \\
\text { ня }\end{array}$ & до лікування & $\begin{array}{c}\text { після лікуван- } \\
\text { ня }\end{array}$ & до лікування & $\begin{array}{c}\text { після лікуван- } \\
\text { ня }\end{array}$ \\
\hline 0 & - & $19(73,1 \%)$ & - & $15(53,6 \%)$ & - & - \\
\hline 1 & $24(92,3 \%)$ & $7(26,9 \%)$ & $20(71,4 \%)$ & $13(46,4 \%)$ & $15(62,5 \%)$ & $22(91,7 \%)$ \\
\hline 2 & $2(7,7 \%)$ & - & $8(28,6 \%)$ & - & $9(37,5 \%)$ & $2(8,3 \%)$ \\
\hline
\end{tabular}

Висновки. 1. Одним із вирішальних фракторів ефективності лікування менопаузальних генітоуринарних порушень $є$ фрактор часу. Результативність заходів корекції зазначеної патології найкраща, якщо тривалість порушень не більше 3 років. При більших термінах перебігу ефрективність лікування зменшується та стає доволі малоефективною.

2. Враховуючи той фракт, що завдяки фрізіологічним, невідступним гормональним змінам у жіночому організмі клімактеричні розлади значно впливають на повсякденне життя зі зниженням його якості, найбільш раціональним
$€$ не лікування срактичних порушень, проте їх попередження ще з періоду пременопаузи.

ПЕРСПЕКТИВИ ПОДАЛЬШИХ ДОСЛІДЖЕНЬ. ДОСЛідити особливості призначення комплексної медикаментозної терапії в жінок менопаузального віку, що страждають від метаболічного синдрому, з метою визначення оптимальних методик. Детально вивчити ефективність застосування лікувальної гімнастики Кегеля для даної категорії пацієнток. У межах отриманих результатів доповнити існуючі клінічні протоколи рекомендаціями щодо профілактики й своєчасної корекції менопаузальних генітоуринарних порушень.

\section{СПИСОК ЛІТЕРАТУРИ}

1. American College of Obstetricians and Gynecologists. ACOG Practice Bulletin No. 141: management of menopausa symptoms // Obstet. Gynecol. - 2014. - Vol. 123 (1). - P. 202-216.

2. The influence of climacteric symptoms on women's lives and activities / A. Bień, E. Rzońca, G. Iwanowicz-Palus, M. Pańczyk-Szeptuch // Int. J. Environ. Res. Public Health. 2015. - Vol. 3; 12 (4). - P. 3835-3846.

3. Ortmann $\mathrm{O}$. The treatment of climacteric symptoms / O. Ortmann // Dtsch. Arztebl. Int. - 2012. - Vol. 109 (17). P. 316-323.

4. Dalal P. K. Postmenopausal syndrome / P. K. Dalal, M. Agarwal // Indian J. Psychiatry. - 2015. - Vol. 57 (Suppl. 2). P. S222-232.

5. The symptomatology of climacteric syndrome: whether associated with the physical factors or psychological disorder in perimenopausal/postmenopausal patients with anxiety- depression disorder / B. Zhou, X. Sun, M. Zhang [et al.] // Arch. Gynecol. Obstet. - 2012. - Vol. 285 (5). - P. 1345-1352.

6 . Symptoms of menopause - global prevalence, physiology and implications / P. Monteleone, G. Mascagni, A. Giannini [et al.] // Nat. Rev. Endocrinol. - 2018. - Vol. 2.

7. Long-term nonhormonal treatment of vaginal dryness / G. A. Bachmann, M. Notelovitz, S. J. Kelly [et al] // Clin. Pract. Sex. - Vol. 8 (12). - P. 1992.

8. Urogenitale ageing and its effect on sexual health in older British women / Br. J. Obstet. Gynaec. - 1997. - Vol. 104. P. 87-91.

9. Fourth international consultation on incontinence recommendations of the international scientific committee: Evaluation and treatment of urinary incontinence, pelvic organ prolapse, and fecal incontinence / P. Abrams, K. E. Andersson, L. Birder [et al.] // Neurourol. Urodyn. - 2010. - Vol. 29 (1). - P. 213-240. 


\section{REFERENCES}

1. (2014). American College of Obstetricians and Gynecologists. ACOG Practice Bulletin No. 141: management of menopausal symptoms. Obstet. Gynecol., 123 (1), 202-216.

2. Bień, A., Rzońca, E., Iwanowicz-Palus, G., PańczykSzeptuch, M. (2015). The influence of climacteric symptoms on women's lives and activities. Int. J. Environ. Res. Public Health., 3; 12 (4), 3835-3846.

3. Ortmann, O. (2012). The treatment of climacteric symptoms. Dtsch. Arztebl. Int., 109 (17), 316-323.

4. Dalal, P.K., \& Agarwal, M. (2015). Postmenopausal syndrome. Indian J. Psychiatry, 57 (Suppl. 2), 222-232.

5. Zhou, B., Sun, X., Zhang, M., Deng, Y., \& Hu, J. (2012). The symptomatology of climacteric syndrome: whether associated with the physical factors or psychological disorder in perimenopausal/postmenopausal patients with anxiety-depression disorder. Arch. Gynecol. Obstet., 285 (5), 1345-1352.
6. Monteleone, P., Mascagni, G., Giannini, A., Genazzani, A.R., Simoncini, T. (2018). Symptoms of menopause - global prevalence, physiology and implications. Nat. Rev. Endocrinol.

7. Bachmann, G.A., Notelovitz, M., \& Kelly, S.J. (1992). Long-term non-hormonal treatment of vaginal dryness. Clin. Pract. Sex, 8 (12).

8. Barlow, D.H., Cardozo, L.D., Francis, R.M., Griffin, M., Hart, D.M., Stephens, E., \& Sturdee D.W. (1997). Urogenitale ageing and its effect on sexual health in older British women. Br. J. Odstet. Gynaec., 104, 87-91.

9. Abrams, P., Andersson, K.E., \& Birder, L. (2010). Fourth international consultation on incontinence recommendations of the international scientific committee: Evaluation and treatment of urinary incontinence, pelvic organ prolapse, and fecal incontinence. Neurourol. Urodyn., 29 (1), 213-240.

Отримано 12.01 .18 